\title{
Maternal overweight and its relation with child's anthropometric indices
}

Marcela Martins Soares 1

(iD) https://orcid.org/0000-0001-9920-2814

Leidjaira Lopes Juvanhol 2

(iD https://orcid.org/0000-0001-8012-6006

Andreia Queiroz Ribeiro 3

(iD https://orcid.org/0000-0001-6546-1252

Patrícia Feliciano Pereira 4

(iD) https://orcid.org/0000-0001-6103-2944
Sylvia C. C. Franceschini 5

iD https://orcid.org/0000-0001-7934-4858

Raquel Maria Amaral Araújo 6

iD https://orcid.org/0000-0003-1323-8707

1-6 Programa de Pós Graduação de Ciência da Nutrição. Departamento de Nutrição e Saúde. Centro de Ciências Biológicas. Universidade Federal de Viçosa. Campus Viçosa, s.n. Viçosa, MG, Brasil. CEP: 36.570-900. E-mail: marcela.m.soares@ufv.br

\begin{abstract}
Objectives: to investigate the relation between maternal overweight and child's anthropometric indices, identifying the interaction with the child's age.

Methods: a cross-sectional study with mothers and their children under 2 years old. The mothers' body mass index (BMI), waist-to-hip ratio and waist-to-height ratio was calculated. In children, we calculated height/age (H/A), body mass index/age (BMI/A), weight/height $(W / H)$ and weight/age $(W / A)$ indices. The means of the anthropometric indices of children with excess weight and maternal cardiometabolic risk were compared. Mothers and children's anthropometric indices were correlated. Linear regression models were proposed. We investigated the child's age interaction with anthropometric variables of the dyad.

Results: the means of BMI/A and W/H were higher in children of overweight mothers and the means of $B M I / A, W / H$ and $W / A$ were higher when mothers had increased risk for cardiometabolic diseases. There was an association of maternal weight and height with the W/A index; maternal BMI with W/H; maternal height with $H / A$; maternal weight, BMI and waist circumference with BMI/A. The children's age did not interact with the assessed parameters.

Conclusion: children under 2 years of age, whose mothers are overweight, tend to show changes in weight, regardless of age.

Key words Child, Mothers, Nutritional status, Anthropometry
\end{abstract}

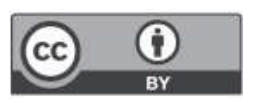




\section{Introduction}

Adequate nutritional status is one of the determining factors for a good health condition. ${ }^{1}$ The prevalence of overweight and obesity has been growing over the years. According to the World Health Organization (WHO), this comorbidity is considered one of the major public health problems in the world. In Brazil, surveys indicate a prevalence of more than $50 \%$ of overweight among adults and about 15\% among children, with emphasis in the Southeast and South regions. ${ }^{2}$

It is estimated that more than 41 million children worldwide, aged up to five years old, are overweight. 3 This condition is considered as one of the risk factors to develop chronic non-communicable diseases (NCDs), being the most concerning in the earlier occurrence.4-6

Infant nutritional status can be related to both genetic and environmental factors. Studies reveal that in the gestational period, the maternal nutritional status has been related to the nutritional status of their children.7-10 However, it is noteworthy that this relationship between mother and child is also verified throughout childhood and adolescence.11-17

A study conducted with children under the age of five, found a relationship between the mothers and children's Body Mass Index (BMI), identifying a lower prevalence of overweight in children of eutrophic mothers. It was also verified a relationship between the height of the dyad, with a three times greater chance of the child being short when the mothers present it. 13 Cantalice et al. 12 also found a relationship between maternal nutritional status and overweight in children and adolescents between 2 and 18 years old. Mascarenhas et al. ${ }^{11}$ verified that the risk of an adolescent (10 to 17 years old) presenting overweight/obesity is 2.28 times when his/her mother presents this condition, thus maternal obesity is an overweight risk factor.

The relationship between the nutritional status of the mother-child dyad, considering the family context and the environment, is poorly studied, especially in the first years of life, which highlights the need to understand it better. We know that environmental conditions play an important role in child's growth and development 18,19 and may determine nutritional status over the years. Considering that mothers and children share similar environmental conditions, 12 it is coherent to verify the relationship of the nutritional status of both, though, it is necessary to investigate the child's age interacting in this relationship. Thus, the objective of the present study is to investigate the relationship between maternal overweight and child anthropometric indices, identifying the interaction of the child's age in this relationship.

\section{Methods}

This is a cross-sectional study conducted from December 2016 to November 2018, with mothers and their respective children under two years of age attended at the public health network in the city of Viçosa (MG). The sample calculation suggested 223 pairs (mother and children), although the sample totaled 190 pairs and had a power of $90.7 \%$. The statistical power was calculated using the OpenEpi online software. For the calculation, a significance level of $5 \%$ was considered, exposure of children to overweight according to weight/height $(\mathrm{W} / \mathrm{H})$, as well as prevalence of increased risk for cardiometabolic diseases in mothers, according to the Waist Circumference (WC). We adopted as the inclusion criteria, children up to two years of age and their respective mothers. The non-inclusion criteria adopted were: pregnant mothers; presence of diseases that required changes in the pairs' diet; premature children, as this can be a confounding factor in the interpretation of some results; children under one month old due to high weight retention in mothers.

The data collection took place in five Basic Health Units in the city and in the polyclinic, during puericulture days. We applied a semi-structured questionnaire to obtain information on the demographic, socioeconomic and health conditions of mothers and children. The classification proposed by the Brazilian Association of Research Companies (ABEP) was used to classify the socioeconomic level of the dyad. Data on health conditions refer to the number of prenatal consultations and birth weight and length, information obtained from the mother's prenatal card and the child's health handbook or self-reports by mothers. In addition, we assessed the nutritional status of the dyad.

In mothers, the anthropometric measures assessed were weight, height and waist circumference (WC). Weight was measured in kilograms, using an electronic scale from Kratos ${ }^{\circledR}$ brand, with a maximum capacity of 150 kilograms $(\mathrm{kg})$. Mothers were instructed to get on the center of the scale in an upright position, with arms extended along the body, without shoes and with as little clothing as possible. 20 Height was measured in centimeters with the help of a Altura Exata ${ }^{\circledR}$ stadiometer, with $150 \mathrm{~cm}$ of extension. In order to check this measurement, we instructed the mothers to get on the equipment with 
their backs to the marker, without shoes, with their heels together so that their feet formed a $45^{\circ}$ angle, looking at the horizon and with an upright posture. 20

The Body Mass Index (BMI) was calculated and its classification followed the WHO recommendations, 21 and those with BMI $\geq 25 \mathrm{~kg} / \mathrm{m}^{2}$ were considered overweight. The waist circumference was measured at the midpoint between the lower margin of the last rib and the iliac crest. We adopted the WHO cutoff points for this parameter. ${ }^{21}$ The Waistto-Height Ratio (WHtR) was obtained by the ratio of the value obtained from the $\mathrm{WC}$ by the value of height. We used the cut-off point $\geq 0.5$ indicative of risk for developing cardiovascular diseases. 22

In children, the anthropometric measures assessed were weight and length, which were measured according to techniques recommended by Jelliffe. 20 Weight was measured in kilograms, using a pediatric scale, with a maximum capacity of $16 \mathrm{~kg}$. The children were placed without clothes, lying down or sitting in the center of the scale basket. For children weighing over the capacity, we used the same scale and weighing technique used on mothers. The children's length was measured in centimeters using an infant anthropometer. The measurement was conducted by two properly trained people, so that one of them kept the child's head on the vertical plane and in contact with the fixed part of the anthropometer and the other pressed the child's knees on the surface and moved the mobile part of the equipment. until it forms a $90^{\circ}$ angle between the child's legs and feet, to get the measurement. ${ }^{20}$ The indices of height/age (H/A), Body Mass Index/Age (BMI/A), weight/height $(\mathrm{W} / \mathrm{H})$ and weight/age (W/A) were calculated, in Z-score and assessed according to the cutoff points recommended by WHO, 23 in the WHO Anthro 2011 program version 3.2.2. All anthropometric measurements performed on mothers and children were assessed by a properly trained researcher.

It is noteworthy that the equipment used to measure the weight and height of mothers and children were the same in all Basic Health Units and at the Polyclinic, therefore, they presented the same calibration. It should also be highlighted that the measures were always measured by the researcher responsible for the research, who had the help of an intern. Both were trained to perform these measurements.

Statistical analyzes were performed using the Stata software version 13.0. The Shapiro-Wilk test and asymmetry coefficient were used to assess the normality of the variables. Student's t-test was used to compare the means of children's anthropometric indices according to: maternal nutritional status, considering the presence or absence of overweight according to the BMI; cardiometabolic risk, according to WC and WHtR. Pearson's correlation was conducted between child's anthropometric indices and the mothers' weight and height variables. Linear regression models were proposed considering the child's anthropometric indices (H/A, BMI/A, $\mathrm{W} / \mathrm{H}, \mathrm{W} / \mathrm{A})$ as the outcome and maternal anthropometric variables (weight, height, BMI, WC and WHtR) as explanatory variables. We investigated the existence of interaction of the child's age in the relationship between the child's anthropometric indices and maternal variables. Confounding potentials have been identified in the literature, using the directed acyclic graph (DAG) as a guide in this selection of covariates. This approach has been used to represent causal relationships between variables and to help identify a minimum set of covariates that is sufficient to control the situation of confusion. Based on this strategy, the following covariables were considered: mother's schooling, gestational weight gain, number of pregnancies, maternal age and number of prenatal consultations. The quality of adjustment of the model was assessed by analyzing the residuals (according to the assumptions of normality, homoscedasticity, linearity and independence) as well as by the multicollinearity analysis between the variables included in the model. The level of significance adopted in all analyzes was 5\%.

The study took into account, Resolution 466/12 of the Conselho Nacional da Saúde (CNS) (National Health Council) and was approved by the Human Research Ethics Committee of the Universidade Federal de Viçosa (UFV), under the registration number $1,833,627$. The participation of the dyad occurred voluntarily, and the mothers signed the Informed Consent Form after being informed about the research.

\section{Results}

We assessed 190 mothers and children. The children's mean age was $11.5( \pm 7.8)$ months and mothers $27.4( \pm 6.6)$ years old. Table 1 characterizes the sample, which shows that approximately $54 \%$ of the children were male and $93.7 \%$ had birth weight between $>2,500$ and $<3,999 \mathrm{~g}$. As for gestational parameters, the mean weight gain was $12.7 \mathrm{~kg}$ $( \pm 5.5)$ and about $89 \%$ of mothers attended more than six prenatal consultations. The anthropometric parameters were adequate for most mothers and children. The waist circumference and the waist-toheight ratio showed values indicative of increased 
risk for cardiometabolic diseases for mothers, 57.9\% and $52.1 \%$, respectively. The percentage of overweight in mothers was $43.2 \%$ and in children $6.9 \%$ according to the $\mathrm{W} / \mathrm{A}$ index, $30.5 \%$ by $\mathrm{W} / \mathrm{H}$, and
$31.6 \%$ by BMI/A. Approximately $6 \%$ of the children were below the expected length for their age (Table $1)$.

\section{Table 1}

Socioeconomic and nutritional characteristics of mothers and children attended in a public health network in the city of Viçosa, MG ( $n=190$ pairs).

\begin{tabular}{|c|c|c|}
\hline Variables & $\mathbf{N}$ & $\%$ \\
\hline \multicolumn{3}{|l|}{ Child's sex } \\
\hline Male & 102 & 53.7 \\
\hline Female & 88 & 46.3 \\
\hline \multicolumn{3}{|l|}{ Birth weight (g) } \\
\hline$\leq 2,500$ & 4 & 2.1 \\
\hline$>2,500$ and $<3,999$ & 178 & 93.7 \\
\hline$\geq 4000$ & 8 & 4.2 \\
\hline \multicolumn{3}{|l|}{ Child's age } \\
\hline$<6$ months & 53 & 27.9 \\
\hline 6 months to 1 year & 51 & 26.8 \\
\hline 1 to 2 years & 86 & 45.3 \\
\hline \multicolumn{3}{|l|}{ Maternal schooling } \\
\hline Complete elementary school & 79 & 41.6 \\
\hline Complete high school & 90 & 47.4 \\
\hline Complete higher education & 21 & 11.0 \\
\hline Gestational weight gain $(\bar{X} \pm S D)$ & 12.7 & \pm 5.5 \\
\hline \multicolumn{3}{|l|}{ Prenatal consultations number } \\
\hline$<6$ & 21 & 11.1 \\
\hline$\geq 6$ & 169 & 88.9 \\
\hline \multicolumn{3}{|l|}{ Children's Nutritional status } \\
\hline \multicolumn{3}{|l|}{$\mathrm{H} / \mathrm{A}$} \\
\hline Very low and low & 12 & 6.3 \\
\hline Adequate & 178 & 93.7 \\
\hline \multicolumn{3}{|l|}{ W/A } \\
\hline Very low and low & 5 & 2.6 \\
\hline Adequate & 172 & 90.5 \\
\hline High & 13 & 6.9 \\
\hline \multicolumn{3}{|l|}{ W/H } \\
\hline Thinness & 10 & 5.3 \\
\hline Eutrophy & 122 & 64.2 \\
\hline Overweight & 58 & 30.5 \\
\hline \multicolumn{3}{|l|}{ BMI/A } \\
\hline Thinness & 6 & 3.1 \\
\hline Eutrophy & 124 & 65.3 \\
\hline Overweight & 60 & 31.6 \\
\hline \multicolumn{3}{|l|}{ Mothers' nutritional status } \\
\hline \multicolumn{3}{|l|}{ BMI } \\
\hline$<25.0$ & 108 & 56.8 \\
\hline$\geq 25.0$ & 82 & 43.2 \\
\hline \multicolumn{3}{|l|}{ WC } \\
\hline$<0.80$ & 80 & 42.1 \\
\hline$\geq 0.80$ & 110 & 57.9 \\
\hline \multicolumn{3}{|l|}{ WHtR } \\
\hline$<0.50$ & 91 & 47.9 \\
\hline$\geq 0.50$ & 99 & 52.1 \\
\hline
\end{tabular}

$\mathrm{H} / \mathrm{A}=$ Height by age; W/A = Weight by age; W/H = Weight by height; $\mathrm{BMI} / \mathrm{A}=$ Body Mass Index by age; $\mathrm{BMI}=\mathrm{Body}$ Mass Index; WC = Waist Circumference; HCR = waist-to-height ratio. 
The mean of the W/H and BMI/A indices in children were significantly higher when they were children of overweight mothers. We also found that mothers at increased risk for cardiometabolic diseases, according to $\mathrm{WC}$, had children with higher means for the W/A, W/H and BMI/A indices. The means of the child's anthropometric indices did not differ according to the WHtR (Figure 1). There was a positive correlation between the $\mathrm{W} / \mathrm{A}$ and $\mathrm{W} / \mathrm{H}$ indices with maternal weight, as well as between the $\mathrm{W} / \mathrm{A}$ and $\mathrm{H} / \mathrm{A}$ indices with maternal height (Figure 2).

In the linear regression analysis, we found that the children's W/A index was significantly associated with maternal weight, height and WC. This association was maintained for weight and height in the proposed adjustment model. The $\mathrm{W} / \mathrm{H}$ index was associated with maternal weight and BMI $\left(\geq 25 \mathrm{~kg} / \mathrm{m}^{2}\right)$ in the bivariate analysis, losing the association with weight after the adjustment. In relation to the H/A index, this was associated with maternal height, while the BMI/A index was associated with weight, BMI $\left(\geq 25 \mathrm{~kg} / \mathrm{m}^{2}\right)$ and $\mathrm{WC}(\geq 80 \mathrm{~cm})$, maintaining this association only for the BMI, after the adjustment. As for the explanatory capacity of the indices, maternal height was the variable that best explained the W/A and H/A indices while the maternal BMI best explained the $\mathrm{W} / \mathrm{H}$ and $\mathrm{BMI} / \mathrm{A}$ indices. The children's age did not interact with the assessed parameters (Table 2).

\section{Discussion}

Although the anthropometric parameters have been shown to be adequate for most mothers and children, the prevalence of overweight draws attention. Among mothers, $43.2 \%$ had this condition, a percentage $(50.45 \%)$ lower than that found on the obesity map for adults in the Southeast region. ${ }^{2}$ Among children, the percentage of overweight found was similar $(30.5 \%-\mathrm{W} / \mathrm{H} ; 31.6 \%-\mathrm{BMI} / \mathrm{A})$ to the

Figure 1

Mean and standard deviation of the children's anthropometric measurements and indices, according to the mothers' overweight, waist circumference and waist-to-height ratio. Viçosa, MG $(n=190$ pairs $)$.

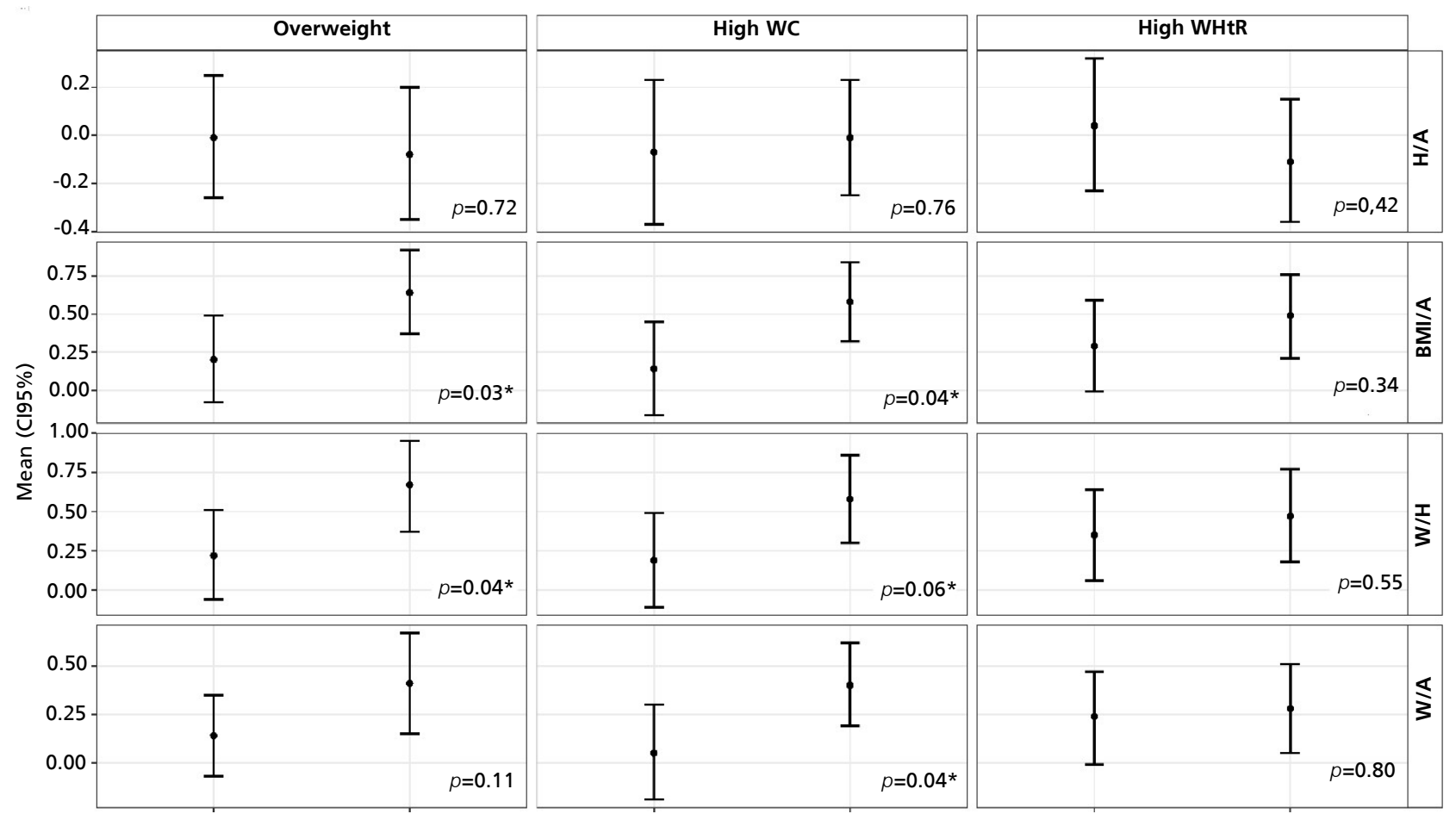

$\mathrm{WC}=$ Waist circumference; $\mathrm{WHtR}=$ waist-to-height ratio; $\mathrm{H} / \mathrm{A}=$ Height by age; $\mathrm{BMI} / \mathrm{A}=$ Body Mass Index by age; $\mathrm{W} / \mathrm{H}=\mathrm{Weight}$ by height; W/A = Weight by age

* Student's t-test.

$* * p<0.05$ 


\section{Figure 2}

Correlation of children's anthropometric indices according to mothers' weight and height. Viçosa, MG ( $\mathrm{n}=190$ pairs).
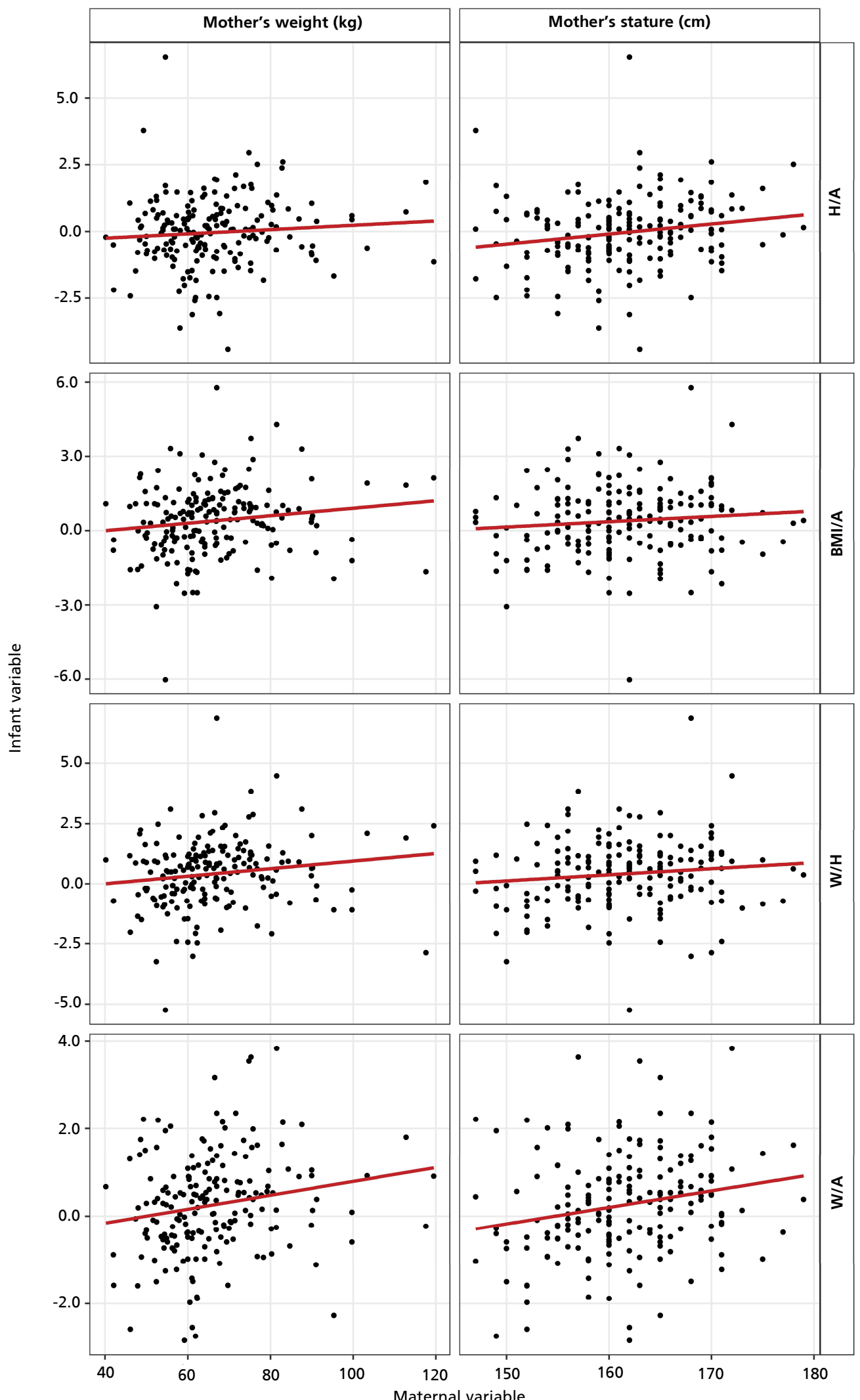

$\mathrm{H} / \mathrm{A}=$ Height by age; $\mathrm{BMI} / \mathrm{A}=$ Body Mass Index by age; $\mathrm{W} / \mathrm{H}=$ Weight by height; W/A = Weight by age. *Pearson's correlation; $* * p<0.05$. 
Linear regression coefficients (gross and adjusted), respective confidence intervals and $p$-value for the association between children's anthropometric indices and maternal anthropometric measurements. Viçosa, MG ( $n=190$ pairs).

\begin{tabular}{|c|c|c|c|c|}
\hline \multirow[t]{3}{*}{ Mothers' variables } & \multirow{2}{*}{$\begin{array}{l}\text { Gross Model } \\
\beta(C 195 \%)\end{array}$} & \multicolumn{3}{|c|}{ Adjusted Model } \\
\hline & & $\beta(C 195 \%)$ & $\mathrm{R}^{2}$ & $p$ interaction $^{1}$ \\
\hline & \multicolumn{4}{|c|}{ H/A Index } \\
\hline Weight (kg) & $0.01(-0.01: 0.02)$ & $0.01(-0.01: 0.02)$ & -1.31 & 0.13 \\
\hline Height $(\mathrm{cm})$ & $0.04(0.01: 0.07)^{*}$ & $0.05(0.02: 0.08)^{*}$ & 3.55 & 0.08 \\
\hline \multicolumn{5}{|l|}{$\mathrm{BMI}$} \\
\hline$<25 \mathrm{~kg} / \mathrm{m}^{2}$ & Ref. & Ref. & -1.62 & 0.32 \\
\hline$\geq 25 \mathrm{~kg} / \mathrm{m}^{2}$ & $-0.07(-0.45 ; 0.31)$ & $-0.13(-0.53 ; 0.26)$ & & \\
\hline \multicolumn{5}{|l|}{ wC } \\
\hline$<80 \mathrm{~cm}$ & Ref. & Ref. & -1.88 & 0.42 \\
\hline$\geq 80 \mathrm{~cm}$ & $0.06(-0.32 ; 0.44)$ & $0.02(-0.38 ; 0.42)$ & & \\
\hline \multicolumn{5}{|l|}{ WHtR } \\
\hline$<0.5$ & Ref. & Ref. & -1.26 & 0.99 \\
\hline \multirow[t]{2}{*}{$\geq 0.5$} & $-0.15(-.053 ; 0.22)$ & $-0.20(-0.59 ; 0.19)$ & & \\
\hline & \multicolumn{4}{|c|}{ BMI/A index } \\
\hline Weight $(\mathrm{kg})$ & $0.02(0.00 ; 0.03)^{*}$ & $0.01(0.00 ; 0.03)$ & 2.86 & 0.99 \\
\hline Height $(\mathrm{cm})$ & $0.02(-0.01 ; 0.05)$ & $0.02(-0.01 ; 0.05)$ & 2.08 & 0.41 \\
\hline \multicolumn{5}{|l|}{ BMI } \\
\hline$<25 \mathrm{~kg} / \mathrm{m}^{2}$ & Ref. & Ref. & 3.87 & 0.34 \\
\hline$\geq 25 \mathrm{~kg} / \mathrm{m}^{2}$ & $0.44(0.04 ; 0.84)^{*}$ & $0.46(0.04 ; 0.88)^{*}$ & & \\
\hline \multicolumn{5}{|l|}{ wc } \\
\hline$<80 \mathrm{~cm}$ & Ref. & Ref. & 2.49 & 0.69 \\
\hline$\geq 80 \mathrm{~cm}$ & $0.44(0.03 ; 0.84)^{*}$ & $0.33(-0.10 ; 0.76)$ & & \\
\hline \multicolumn{5}{|l|}{ WHtR } \\
\hline$<0.5$ & Ref. & Ref. & 1.31 & 0.34 \\
\hline \multirow[t]{2}{*}{$\geq 0.5$} & $0.19(-0.21 ; 0.60)$ & $0.11(-0.30 ; 0.53)$ & & \\
\hline & \multicolumn{4}{|c|}{ W/H index } \\
\hline Weight $(\mathrm{kg})$ & $0.02(0.00: 0.03)^{*}$ & $0.01(0.00 ; 0.03)$ & 3.02 & 0.80 \\
\hline Height $(\mathrm{cm})$ & $0.03(-0.01: 0.06)$ & $0.03(-0.02 ; 0.07)$ & 2.58 & 0.74 \\
\hline \multicolumn{5}{|l|}{ BMI } \\
\hline$<25 \mathrm{~kg} / \mathrm{m}^{2}$ & Ref. & Ref. & 3.82 & 0.42 \\
\hline$\geq 25 \mathrm{~kg} / \mathrm{m}^{2}$ & $0.43(0.02 ; 0.84)^{*}$ & $0.45(0.03 ; 0.88)^{*}$ & & \\
\hline \multicolumn{5}{|l|}{ WC } \\
\hline$<80 \mathrm{~cm}$ & Ref. & Ref. & 2.34 & 0.98 \\
\hline$\geq 80 \mathrm{~cm}$ & $0.39(-0.02 ; 0.80)$ & $0.30(-0.14 ; 0.74)$ & & \\
\hline \multicolumn{5}{|l|}{ WHtR } \\
\hline$<0.5$ & Ref. & Ref. & 1.32 & 0.41 \\
\hline$\geq 0.5$ & $0.12(-0.29 ; 0.53)$ & $0.06(-0.37 ; 0.49)$ & & continue \\
\hline
\end{tabular}

$\mathrm{H} / \mathrm{A}=$ Height by age (z-score); BMI/A = Body Mass Index by age (z-score); W/H = Weight by height (z-score); W/A = Weight by age (z-score); $\beta$ : correlation coefficient; C $195 \%=95 \%$ confidence interval; BMI = B ody Mass Index; WC = Waist Circumference; WHtR = Waist-to-Height R atio.

Model adjusted for the mother's schooling, gestational weight gain, number of pregnancies, maternal age and number of prenatal consultations.

1 Interaction considering age ( $<1$ year and $\geq 1$ year).

2 Model adjusted for the mother's schooling, number of pregnancies, maternal age and number of prenatal consultations.

$* p<0.05$. 
Linear regression coefficients (gross and adjusted), respective confidence intervals and p-value for the association between children's anthropometric indices and maternal anthropometric measurements. Viçosa, MG ( $n=190$ pairs).

\begin{tabular}{|c|c|c|c|c|}
\hline \multirow[t]{3}{*}{ Mothers' variables } & \multirow{2}{*}{$\begin{array}{l}\text { Gross Model } \\
\beta(C 195 \%)\end{array}$} & \multicolumn{3}{|c|}{ Adjusted Model } \\
\hline & & $\beta(C 195 \%)$ & $\mathrm{R}^{2}$ & $p$ interaction ${ }^{1}$ \\
\hline & \multicolumn{4}{|c|}{ Weight / age index } \\
\hline Weight (kg) & $0.02(0.00 ; 0.03)^{*}$ & $0.01(0.00: 0.03)^{*}$ & 4.07 & 0.31 \\
\hline Height $(\mathrm{cm})$ & $0.04(0.02 ; 0.06)^{*}$ & $0.04(0.02: 0.07)^{*}$ & 6.98 & 0.57 \\
\hline BMI & & & 2.42 & \\
\hline$<25 \mathrm{~kg} / \mathrm{m}^{2}$ & Ref. & Ref. & & 0.17 \\
\hline$\geq 25 \mathrm{~kg} / \mathrm{m}^{2}$ & $0.27(-0.06 ; 0.60)$ & $0.25(-0.08 ; 0.58)$ & & \\
\hline WC & & & 2.36 & \\
\hline$<80 \mathrm{~cm}$ & Ref. & Ref. & & 0.86 \\
\hline$\geq 80 \mathrm{~cm}$ & $0.35(0.02 ; 0.68)^{*}$ & $0.25(-0.09 ; 0.60)$ & & \\
\hline WHtR & & & 1.17 & \\
\hline$<0.5$ & Ref. & Ref. & & 0.34 \\
\hline$\geq 0.5$ & $0.04(-0.29 ; 0.37)$ & $-0.04(-0.37 ; 0.30)$ & & \\
\hline
\end{tabular}

$\mathrm{H} / \mathrm{A}=$ Height by age (z-score); BMI/A = Body Mass Index by age (z-score); W/H = Weight by height (z-score); W/A = Weight by age ( $z$-score); $\beta$ : correlation coefficient; C195\% = 95\% confidence interval; BMl = Body Mas s Index; WC = Wais $C$ ircumference; $\mathrm{WHtR}=$ Wais t-to-Height R atio.

Model adjusted for the mother's schooling, gestational weight gain, number of pregnancies, maternal age and number of prenatal consultations.

1 Interaction considering age $(<1$ year and $\geq 1$ year $)$

2 Model adjusted for the mother's schooling, number of pregnancies, maternal age and number of prenatal consultations.

$* p<0.05$.

estimate made by the obesity map (38.8\%), considering children aged 5 to 9 years old in the Southeast region. 2 A study conducted in the Northeast of Brazil, with children under 5 years old also verified a percentage of overweight similar $(28.5 \%)$ to that verified in the present study $(30.5 \%)$, according to the $\mathrm{W} / \mathrm{H}$ index. ${ }^{24}$

The percentage of overweight verified by the W/A index (6.9\%) was lower than the other indices. We believe this is due to the different objectives of the indices. The W/A index, for example, is more suitable for assessing the children's growth, as it reflects the global health situation, but it does not consider whether the impairment is current/acute or progress/chronic. However, it allows to detect easily changes in the child's health status. $18-25 \mathrm{~W} / \mathrm{H}$ is recommended to assess acute malnutrition and overweight, although, it does consider the children's age and may therefore, misclassify their nutritional status when they are short for their age. Thus, it's noteworthy the need to use more than one anthropometric parameter to perform the nutritional diagnosis. 18 Many studies have used the BMI/A index to assess the nutritional status of children and adolescents. $12,13,22,26$ This is due to the fact that this indicator is recommended internationally for the indi- vidual and collective diagnosis of nutritional status, since it considers the individuals' age. 25

Regarding to the relationships between children's anthropometric indices and maternal variables, we found that overweight and/or obese mothers had children with higher means for the anthropometric indicators $\mathrm{W} / \mathrm{H}$ and $\mathrm{BMI} / \mathrm{A}$. This result is similar to a study conducted in Pernambuco with children and adolescents (2 to 18 years old), they have found higher BMI means in mothers when their children were obese. 12 In addition, in the present study, there was a relationship between the children's W/A, W/H and $\mathrm{BMI} / \mathrm{A}$ indices and increased risk for cardiometabolic diseases, according to maternal WC. In a study conducted with children under the age of five, the maternal obesity central was also positively associated with overweight, which was classified according to the $\mathrm{W} / \mathrm{H}$ indicator. ${ }^{24}$ Although little has been studied about the association of maternal WC with the anthropometric indices of children under two years of age, we believe that this relationship is expected, since overweight mothers tend to have high WC.

In the present study, children's anthropometric indices were associated with weight, maternal height, overweight and cardiometabolic risk 
according to WC. Such relationships have also been verified in other studies. In Pernambuco, for example, Miglioli14 found a direct relationship between the W/A of children under five years of age with their mothers' height, and BMI/A with their mothers' BMI. In addition to this, other studies have also found a direct relationship between the maternal BMI and children's BMI.12,13,26 Moreira et al.24 found no relationship between the BMI of mothers and the presence of overweight in children under 5 years of age, which was explained by the authors as a result of the lack of sensitivity of the BMI as an indicator of body fat. However, Murta 13 studying children in this same age group verified a relationship between the mothers and children's BMI, so that the prevalence of overweight in children was lower when they were children of mothers considered to be eutrophic.

When verifying this relationship between children and adolescents, Salvador et al.,26 identified a higher prevalence of overweight among children of mothers with overweight and obesity and Cantalice et al. 12 found a higher BMI means of mothers when their children were obese. A study conducted with children under five years old found that the chance for them being short in stature is three times greater when mothers presents it. ${ }^{13}$ Furthermore, the chance of risk of malnutrition due to $\mathrm{H} / \mathrm{A}$ deficit in children under 6 years of age was two times greater when the mother was less than $155 \mathrm{~cm}$ tall. 27

The W/H and BMI/A indices were better explained by the maternal's BMI, while the W/A and H/A indices were better explained by the maternal's height. This result shows the strong association between the mothers' height and nutritional status on the indices that determine the nutritional status of their children. The use of anthropometry to diagnose the nutritional status of the population, especially in children and adolescents, is very common. Its values represent, for both population and individual levels, the adjustment between environmental factors and genetic potential.28 Such information becomes coherent when identifying an association between maternal anthropometric parameters and the nutritional status of their children, as this association occurs due to the fact of peers share similar social and cultural environments. 12,29

The children's age did not interact with the proposed relationships, that is, the fact that they were in the first or second year of life did not make the relationship between the children's and their mothers' nutritional status different. Thus, we assume that this relationship between the nutritional status of the mother-child dyad does not occur only with children older than two years of age and adolescents, 11-17,24,26,27 but also in the early period of life. Therefore, we highlight the importance of considering the maternal nutritional condition in monitoring the child's nutrition from the beginning of life, aiming to prevent health risk conditions, such as, for example, chronic non-communicable diseases.

We conclude that children, under two years of age of overweight mothers, present changes in the weight/age and weight/height indices, regardless of age. Such information can contribute to direct healthcare in the period of the child's first thousand days of life. It is evident, therefore, the necessity of actions to promote health and prevent nutritional problems in children, which also include care for maternal nutrition in this period.

\section{Authors' contribution}

Soares MM and Araújo RMA contributed to the conception and the design of the study, analysis and interpretation of data, writing and critical review of the content of the article. Juvanhol LL, Ribeiro AQ, Pereira PF and Franceschini SCC contributed to the analysis and interpretation of data, critical review of the content of the article. All authors approved the final version of the article.

\section{References}

1. Silveira JAC, Colugnati FA, Poblacion AP, Taddei JA. Association between socioeconomic and biological factors and infant weight gain: Brazilian Demographic and Health Survey - PNDS-2006/07. J Pediatr. 2015; 91 (3): 284-91.

2. ABESO (Associação Brasileira para o Estudo da Obesidade e da Síndrome Metabólica). Mapa da obesidade. s/d. [acesso 27 jun 2019]. Disponível em: http://www.abeso.org.br/atitude-saudavel/mapa-obesidade.

3. WHO (World Health Organization). Childhood over weight

and obesity. Geneva; World Health Organization (WHO). 2014 [acesso 29 nov 2018]. Disponível em: http://www.who.int/dietphysicalactivity/ childhood/en

4. WHO (World Health Organization).Essential nutrition actions: improving maternal, newborn, infant and young child health and nutrition. Geneva; 2013

5. WHO (World Health Organization).Global status report on noncommunicable diseases 2014. Geneva; 2014.

6. Nunes AA, Nunes MSS, Silva AS, Mello LM. Obesidade 
na infầncia. Pediatr Mod. 2015; 51 (7): 263-72.

7. Godfrey KM, CostelloPM, Lillycrop KA. Development, epigenetics and metabolic programming. Nestle Nutr Inst Workshop Ser. 2016; 85:71-80.

8. Hannaford KE, Tuuli MG, Odibo L, Macones GA, Odibo AO. Gestational Weight Gain: Association with Adverse Pregnancy Outcomes. Am J Perinatol. 2017; 34 (2):147-54.

9. Kanob JI, Bottaro SM, Kirchner RM. Correlação entre o estado antropométrico materno e do recém-nascido. Rev Associação Bras Nutr. 2016; 2: 31-7.

10. Oliveira, ACM, Pereira LA, Ferreira RC, Clemente APG Estado nutricional materno e sua associação com o peso ao nascer em gestantes de alto risco. Ciênc Saúde Coletiva. 2018; 23 (7): 2373-82.

11. Mascarenhas LPG, Modesto MJ, Amer NM, Boguszewski MCS, Lacerda Filho L, Prati FS. Influência do excesso de peso dos pais em relação ao sobrepeso e obesidade dos filhos. Pensar Prát. 2013; 16 (2): 320-618.

12. Cantalice ASC, Santos NCCB, Silva DCM, Collet N, Reichert APS, Medeiros CCM. Estado nutricional materno e o excesso de peso em crianças e adolescentes. Rev Bras Nutr Clin. 2015; 30 (1): 39-44.

13. Murta TGH. Fatores associados a desfechos nutricionais em mães e crianças brasileiras [tese]. Belo Horizonte: Escola de Enfermagem da Universidade Federal de Minas Gerais 2016.

14. Miglioli TC. Estado nutricional de mães e filhos menores de cinco anos em Pernambuco: marcadores antropométricos, anemia e deficiência de vitamina A [tese] Rio de Janeiro: Instituto Nacional da Mulher e da Criança e do Adolescente Fernandes Figueira; 2014.

15. Silva D, Valente A, Borges A, Dias C, Almeida F, Cruz JL, Neves E, Afonso C, Guerra A. Avaliação entre o estado nutricional materno e o de uma população infantil de São Tomé e Príncipe "África". Rev Bras Saúde Mater Infant. 2017; 17 (2): 327-35.

16. Negash C, Whiting SJ, Henry CJ, Belachew T, Hailemariam TG. Association between Maternal and Child Nutritiona Status in Hula, Rural Southern Ethiopia: A Cross SectionalStudy. PloS One 2015; 10 (11): e0142301.

17. Keino S, Plasqui G, Ettyang G, Van den Borne, B Determinants of Stunting and Overweight among Young Children and Adolescents in Sub-Saharan Africa. Food Nutr Bull. 2014; 35(2): 167-78.
18. Brasil. Ministério da Saúde. Secretaria de Políticas de Saúde. Departamento de Atenção Básica. Saúde da criança: acompanhamento do crescimento e desenvolvimento infantil. Brasília, DF; 2002.

19. Carvalho AC, Fonseca PCA, Priore SE, Franceschini SCC, Novaes JF. Consumo alimentar e adequação nutricional em crianças brasileiras: revisão sistemática. Rev Paul Pediatr. 2015;33 (2): 211-21.

20. Jelliffe DB. The assessment of the nutritional status of the community. Geneva: WHO; 1966.

21. WHO (World Health Organization). Obesity: preventing and managing the global epidemic. Geneva: World Health Organization (WHO Technical Report Series 894); 1998.

22. Ashwell M, Hsieh SD. Six reasons why the waist-to-height ratio is a rapid and effective global indicator for health risks of obesity and how its use could simplify the international public health message on obesity. Int J Food Sci Nutr. 2005; $56(5): 303-7$

23. WHO (World Health Organization).Indicators for assessing infant and young child feeding practices. Washington, DC; 2007

24. Moreira MA, Cabral PC, Ferreira HS, Lira PIC.Overweight and associated factors in children from northeasten Brazil.J Pediatr. 2012; 88 (4): 347-52.

25. Fontes GAV, Mello AL, Sampaio LR. Manual de avaliação nutricional e necessidade energética de crianças e adolescents: uma aplicação prática. Salvador: EDUFBA; 2012. $88 \mathrm{p}$.

26. Salvador CCZ, Kitoko PM, Gambardella AMD. Estado nutricional de crianças e adolescentes: fatores associados ao excesso de peso e acúmulo de gordura. Rev Bras Crescimento Desenvolv Hum. 2014, 24 (3): 313-9.

27. Silveira KBR, Alves JFR, Ferreira HS, Sawaya AL, Florêncio TMMT.Associação entre desnutrição em crianças moradoras de favelas, estado nutricional materno e fatores socioambientais. J Pediatr. 2010; 86 (3): 215-20.

28. Pedraza DF, Souza MM, Rocha AND. Fatores associados ao estado nutricional de crianças pré-escolares brasileiras assistidas em creches públicas: uma revisão sistemática. RevNutr. 2015; 28 (4): 451-64

29. Giacomossi MC, Zanella T, Hofelmann DA. Percepção materna do estado nutricional de crianças de creches de cidade do sul do Brasil. Rev Nutr. 2011; 4 (5): 689-702.

Received on December 30, 2019

Final version presented on December 28, 2020

Approved on February 15, 2021 